\title{
Safety Testing of AGR-2 UCO Compacts 6-4-2 and 2-3-1
}

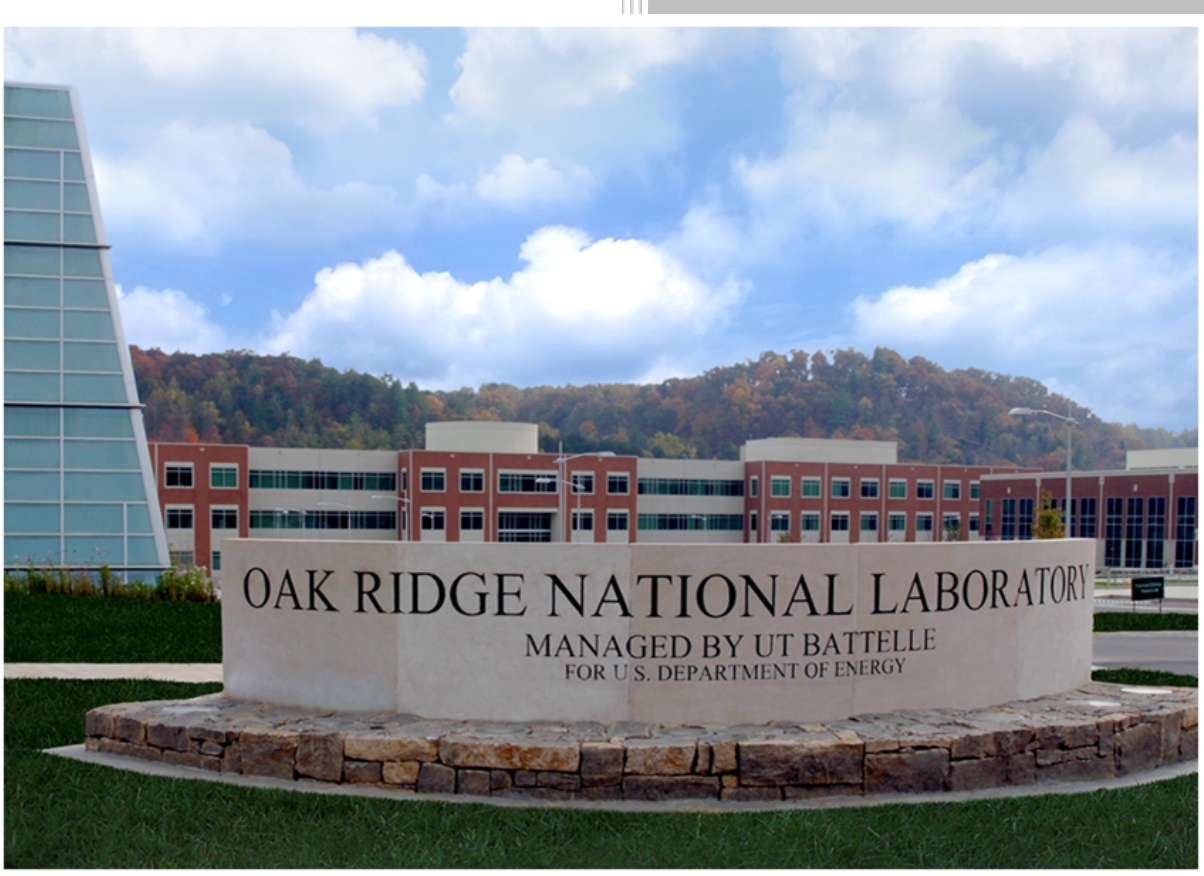

Approved for public release. Distribution is unlimited.

John D. Hunn

Robert N. Morris Charles A. Baldwin Zachary M. Burns Fred C. Montgomery Darren J. Skitt

August 2017 


\title{
DOCUMENT AVAILABILITY
}

Reports produced after January 1, 1996, are generally available free via US Department of Energy (DOE) SciTech Connect.

Website http://www.osti.gov/scitech/

Reports produced before January 1, 1996, may be purchased by members of the public from the following source:

\author{
National Technical Information Service \\ 5285 Port Royal Road \\ Springfield, VA 22161 \\ Telephone 703-605-6000 (1-800-553-6847) \\ TDD 703-487-4639 \\ Fax 703-605-6900 \\ E-mail info@ntis.gov \\ Website http://www.ntis.gov/help/ordermethods.aspx
}

Reports are available to DOE employees, DOE contractors, Energy Technology Data Exchange representatives, and International Nuclear Information System representatives from the following source:

Office of Scientific and Technical Information

PO Box 62

Oak Ridge, TN 37831

Telephone 865-576-8401

Fax 865-576-5728

E-mail reports@osti.gov

Website http://www.osti.gov/contact.html

This report was prepared as an account of work sponsored by an agency of the United States Government. Neither the United States Government nor any agency thereof, nor any of their employees, makes any warranty, express or implied, or assumes any legal liability or responsibility for the accuracy, completeness, or usefulness of any information, apparatus, product, or process disclosed, or represents that its use would not infringe privately owned rights. Reference herein to any specific commercial product, process, or service by trade name, trademark, manufacturer, or otherwise, does not necessarily constitute or imply its endorsement, recommendation, or favoring by the United States Government or any agency thereof. The views and opinions of authors expressed herein do not necessarily state or reflect those of the United States Government or any agency thereof. 
Fusion and Materials for Nuclear Systems Division

\title{
SAFETY TESTING OF AGR-2 UCO COMPACTS 6-4-2 AND 2-3-1
}

\author{
John D. Hunn \\ Robert N. Morris \\ Charles A. Baldwin \\ Zachary M. Burns \\ Fred C. Montgomery \\ Darren J. Skitt
}

Revision 0

Date Published: August 2017

\author{
Work sponsored by \\ US DEPARTMENT OF ENERGY \\ Office of Nuclear Energy - Advanced Reactor Technologies \\ under the \\ Advanced Gas Reactor Fuel Development and Qualification Program
}

Prepared by

OAK RIDGE NATIONAL LABORATORY

Oak Ridge, TN 37831-6283

managed by

UT-BATTELLE, LLC

for the

US DEPARTMENT OF ENERGY

under contract DE-AC05-00OR22725 



\section{CONTENTS}

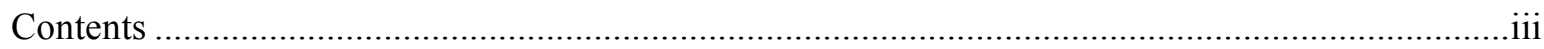

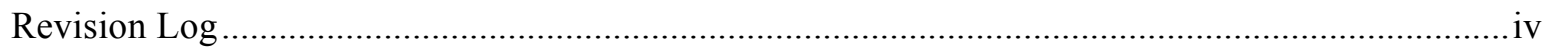

List of Figures

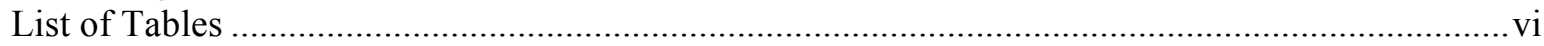

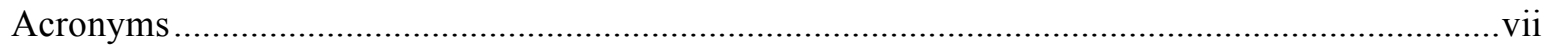

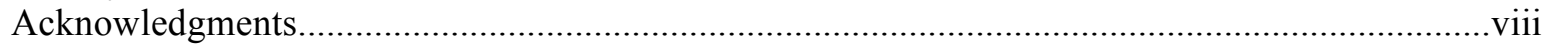

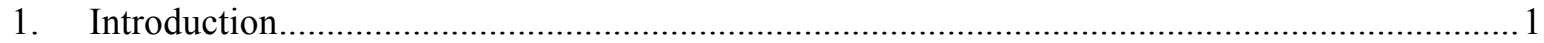

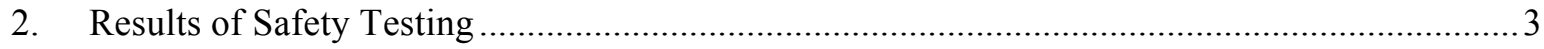

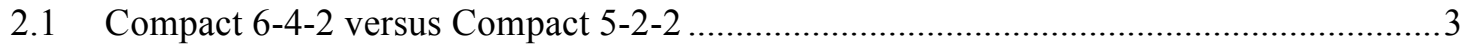

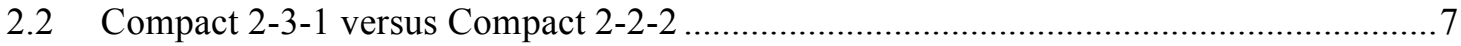

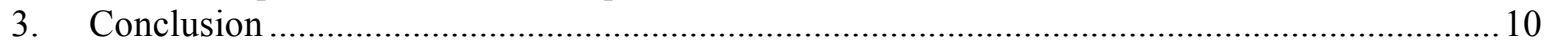

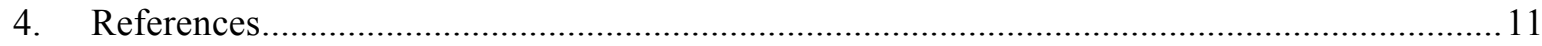




\section{REVISION LOG}

\begin{tabular}{|c|c|c|c|}
\hline Revision & Date & Affected Pages & Revision Description \\
\hline 0 & & All & Initial issue \\
\hline
\end{tabular}




\section{LIST OF FIGURES}

1. Release of fission products from Compact 6-4-2 during safety testing to $1600^{\circ} \mathrm{C}$.....................

2. Release of fission products from Compact 5-2-2 during safety testing to $1600^{\circ} \mathrm{C}$. ...................4

3. Ratio of ${ }^{110 \mathrm{~m}} \mathrm{Ag}$ retained in 43 Compact 6-4-2 particles after safety testing to $1600^{\circ} \mathrm{C}$...............5

4. Ratio of ${ }^{110 \mathrm{~m}} \mathrm{Ag}$ retained in 55 Compact 5-2-2 particles after safety testing to $1600^{\circ} \mathrm{C} \ldots \ldots \ldots \ldots . . .5$

5. Rate of fission product release from Compact 6-4-2 during safety testing to $1600^{\circ} \mathrm{C}$...............6

6. Rate of fission product release from Compact 5-2-2 during safety testing to $1600^{\circ} \mathrm{C}$...............6

7. Release of fission products from Compact 2-3-1 during safety testing to $1600^{\circ} \mathrm{C}$. ....................

8. Release of fission products from Compact 2-2-2 during safety testing to $1600^{\circ} \mathrm{C}$. ....................8

9. Rate of fission product release from Compact 2-3-1 during safety testing to $1600^{\circ} \mathrm{C} \ldots \ldots \ldots \ldots \ldots . . . .9$

10. Rate of fission product release from Compact 2-2-2 during safety testing to $1600^{\circ} \mathrm{C} \ldots \ldots \ldots \ldots . . . .9$ 


\section{LIST OF TABLES}

1. Irradiation conditions for AGR-2 UCO Compacts safety tested at $1600^{\circ} \mathrm{C}$ .2

2. Radioactive isotope distribution on furnace internal components after the Compact 6-4-2 safety test ....

3. Radioactive isotope distribution on furnace internal components after the Compact 5-2-2 safety test .....

4. Radioactive isotope distribution on furnace internal components after the Compact 2-3-1 safety test .8

5. Radioactive isotope distribution on furnace internal components after the Compact 2-2-2 safety test .8

6. Cumulative releases of radioactive isotopes from AGR-2 UCO TRISO $1600^{\circ} \mathrm{C}$ safety tests 10 


\section{ACRONYMS}

AGR

AGR-1

AGR-2

BWXT

CCCTF

$\mathrm{CO}$

DLBL

FACS

FIMA

HTGR

ID

IFEL

IMGA

INL

LBL

OPyC

ORNL

PIE

$\mathrm{SiC}$

TAVA

TRISO

$\mathrm{UCO}$

$\mathrm{UO} 2$
Advanced Gas Reactor (Fuel Development and Qualification Program)

First AGR program irradiation experiment

Second AGR program irradiation experiment

BWX Technologies

Core Conduction Cooldown Test Facility

Carbon monoxide

Deconsolidation leach-burn-leach

Fuel Accident Condition Simulator

Fissions per initial metal atom

High Temperature Gas-cooled Reactor

Identification

Irradiated Fuels Examination Laboratory (hot cells)

Irradiated Microsphere Gamma Analyzer

Idaho National Laboratory

Leach-burn-leach

Outer pyrolytic carbon (TRISO layer)

Oak Ridge National Laboratory

Post-irradiation examination

Silicon carbide (TRISO layer)

Time-averaged/volume-averaged temperature

Tristructural-isotropic (coated particles)

Uranium carbide/uranium oxide mixture (fuel kernels)

Uranium dioxide (fuel kernels) 


\section{ACKNOWLEDGMENTS}

This work was sponsored by the U.S. Department of Energy, Office of Nuclear Energy, through the Idaho National Laboratory Advanced Reactor Technologies Technology Development Office as part of the Advanced Gas Reactor Fuel Development and Qualification Program. Analysis of leach solutions and Core Conduction Cooldown Test Facility furnace components was provided by the Oak Ridge National Laboratory Nuclear Analytical Chemistry \& Isotopics Laboratory. Hot cell activities were supported by the staff of the Oak Ridge National Laboratory Irradiated Fuels Examination Laboratory. 


\section{INTRODUCTION*}

Post-irradiation examination (PIE) and elevated-temperature safety testing are being performed on tristructural-isotropic (TRISO) coated-particle fuel compacts from the Advanced Gas Reactor (AGR) Fuel Development and Qualification Program second irradiation experiment (AGR-2). Details on this irradiation experiment have been previously reported [Collin 2014]. The AGR-2 PIE effort builds upon the understanding acquired throughout the AGR-1 PIE campaign [Demkowicz et al. 2015] and is establishing a database for the different AGR-2 fuel designs.

The AGR-2 irradiation experiment included TRISO fuel particles coated at BWX Technologies (BWXT) with a $150-\mathrm{mm}$-diameter engineering-scale coater. Two coating batches were tested in the AGR-2 irradiation experiment. Batch 93085 had 508- $\mu$ m-diameter uranium dioxide $\left(\mathrm{UO}_{2}\right)$ kernels. Batch 93073 had 427 - $\mu$ m-diameter UCO kernels, which is a kernel design where some of the uranium oxide is converted to uranium carbide during fabrication to provide a getter for oxygen liberated during fission and limit CO production. Fabrication and property data for the AGR-2 coating batches have been compiled [Barnes and Marshall 2009] and compared to AGR-1 [Phillips, Barnes, and Hunn 2010]. The AGR-2 TRISO coatings were most like the AGR-1 Variant 3 TRISO deposited in the 50-mm-diameter ORNL lab-scale coater [Hunn and Lowden 2006]. In both cases, the hydrogen and methyltrichlorosilane coating gas mixture employed to deposit the $\mathrm{SiC}$ was diluted with argon to produce a finer-grain, more equiaxed SiC microstructure [Lowden 2006; Gerczak et al. 2016]. In addition to the fact that AGR-1 fuel had smaller, $350-\mu \mathrm{m}$-diameter UCO kernels, notable differences in the TRISO particle properties included the pyrocarbon anisotropy, which was slightly higher in the particles coated in the engineeringscale coater, and the exposed kernel defect fraction, which was higher for AGR-2 fuel due to the detected presence of particles with impact damage introduced during TRISO particle handling [Hunn 2010].

Irradiation test compacts containing AGR-2 fuel particles were compacted at ORNL with the same resinated-graphite blend used to make AGR-1 compacts and a modified pressing process that utilized a die heated to $65^{\circ} \mathrm{C}$ and a new computer-controlled servo-press. Two compact lots were produced and qualified for the AGR-2 irradiation test: lot LEU09-OP2-Z contained the UCO TRISO particles [Hunn, Montgomery, and Pappano 2010a] and lot LEU11-OP2-Z contained the $\mathrm{UO}_{2}$ fuel [Hunn, Montgomery, and Pappano 2010b]. Compared to the AGR-1 compacts, which were compacted at room temperature using a manual press, the modified AGR-2 compacting process produced compacts with reduced variability in length and higher matrix density (1.6-1.7 g/cc for AGR-2 versus $1.2-1.3 \mathrm{~g} / \mathrm{cc}$ for AGR-1). Compilations of the properties data for the particles and compacts are available in pre-irradiation characterization summary reports for the AGR-1 [Hunn, Savage, and Silva 2012] and AGR-2 [Hunn, Savage, and Silva 2010] fuel composites.

The AGR-2 Post-Irradiation Examination Plan [Demkowicz 2013] includes safety testing of the irradiated compacts in the Oak Ridge National Laboratory (ORNL) Core Conduction Cooldown Test Facility (CCCTF) and the Idaho National Laboratory (INL) Fuel Accident Condition Simulator (FACS) to evaluate the effect of elevated temperature on fuel microstructure, individual particle coating failure, and overall fission product ${ }^{\dagger}$ retention. The safety tests involve heating compacts in flowing helium to maximum temperatures of 1600,1700 , or $1800^{\circ} \mathrm{C}$ and holding at these temperatures for approximately $300 \mathrm{~h}$. The standard test temperature of $1600^{\circ} \mathrm{C}$ is the expected maximum temperature during a hightemperature gas-cooled reactor (HTGR) depressurization conduction-cooldown event, while $1700^{\circ} \mathrm{C}$ and $1800^{\circ} \mathrm{C}$ tests explore the safety margin and provide additional data on mechanisms for particle coating

\footnotetext{
${ }^{*}$ Background content in this introduction section has appeared in a previous AGR-2 PIE report [Hunn et al. 2016a].

"In this report, the term "fission product" is used in a general sense to refer to all the post-fission isotopes remaining at the end of the irradiation test. These include: isotopes directly generated by the fission process, isotopes generated by neutron activation, isotopes generated by radioactive decay, and residual uranium.
} 
failure, fission product diffusion, and other fission product interactions with the TRISO coatings. The first two CCCTF AGR-2 safety tests were performed on AGR-2 $\mathrm{UO}_{2}$ Compacts 3-3-2 and 3-4-2; both were heated to $1600^{\circ} \mathrm{C}$ in flowing helium for $300 \mathrm{~h}$ and results were summarized in a previous report [Hunn et al. 2015a]. These $\mathrm{UO}_{2}$ Compacts both exhibited multiple particle failure at $1600^{\circ} \mathrm{C}$ due to $\mathrm{CO}$ corrosion, which is in sharp contrast to the performance of the UCO compacts that have been safety tested thus far [Morris et al. 2016].

In this report, new results of $1600^{\circ} \mathrm{C}$ safety testing on AGR-2 UCO Compacts 6-4-2 and 2-3-1 are reported and compared to previously reported results [Hunn et al. 2016a] from the other two $1600^{\circ} \mathrm{C}$ safety tests on AGR-2 UCO compacts completed thus far (Compacts 5-2-2 and 2-2-2). Table 1 shows the calculated burnup in percent fissions per initial metal atom (FIMA), the fast neutron fluence (neutron energies $>0.18 \mathrm{MeV}$ ), and the average compact temperatures during irradiation for these four compacts. Compact 5-2-2 represents the baseline AGR-2 irradiation condition. Compact 6-4-2 was irradiated to a lower irradiation dose and temperature. Compacts 2-3-1 and 2-2-2 were irradiated under similar conditions, but at notably higher temperature than the baseline condition.

Table 1. Irradiation conditions for AGR-2 UCO Compacts safety tested at $1600^{\circ} \mathrm{C}$

\begin{tabular}{|c|c|c|c|c|c|}
\hline Compact ID $^{a}$ & Fabrication ID $^{b}$ & Fuel Type & $\begin{array}{c}\text { Average Burnup }{ }^{c} \\
\text { (\%FIMA) }\end{array}$ & $\begin{array}{l}\text { Fast Fluence }{ }^{c} \\
\left(\mathrm{n} / \mathrm{m}^{2}\right)\end{array}$ & $\begin{array}{c}\text { Temperature }{ }^{\mathrm{d}} \\
\left({ }^{\circ} \mathrm{C}\right)\end{array}$ \\
\hline AGR-2 6-4-2 & LEU09-OP2-Z049 & UCO & 9.26 & $2.21 \times 10^{25}$ & 1018 \\
\hline AGR-2 5-2-2 & LEU09-OP2-Z128 & $\mathrm{UCO}$ & 12.34 & $3.39 \times 10^{25}$ & 1141 \\
\hline AGR-2 2-3-1 & LEU09-OP2-Z125 & $\mathrm{UCO}$ & 12.63 & $3.42 \times 10^{25}$ & 1296 \\
\hline AGR-2 2-2-2 & LEU09-OP2-Z075 & $\mathrm{UCO}$ & 12.55 & $3.39 \times 10^{25}$ & 1287 \\
\hline
\end{tabular}

Safety testing in the CCCTF furnace was accomplished with the same methods used for AGR-1 safety testing [Baldwin et al. 2012]. Compacts were placed in a graphite holder that positions the compact in the furnace and simulates the graphite that surrounds the compacts in a prismatic-block reactor. A watercooled deposition cup located near the top of the tantalum-lined furnace chamber collected vaporized metallic elements that escaped from the compact and surrounding graphite holder. Deposition cups were periodically removed and replaced with a new cup using a maximum exchange interval of $\sim 24 \mathrm{~h}$ and shorter exchange intervals for the first few cups removed after heating up to the test temperature. The cups were monitored with gamma spectrometry to track safety test progress, with particular emphasis on collected cesium inventory that would indicate $\mathrm{SiC}$ failure [Hunn et al. 2014a]. Gaseous fission products were collected from the helium sweep gas as it passed through a liquid-nitrogen-cooled trap that was monitored for ${ }^{85} \mathrm{Kr}$ because significant and rapid krypton release would indicate complete failure of a TRISO coating [Morris et al. 2014]. After completion of each safety test, additional analysis was performed to measure fission products on the deposition cups and other CCCTF furnace internals (graphite fuel holder, tantalum furnace liner, and tantalum gas inlet line). This allowed for the determination of an average deposition cup collection efficiency for each detected fission product, and this efficiency value was used to adjust the time-dependent deposition cup data to estimate the timedependent fission product release from the compact. 


\section{RESULTS OF SAFETY TESTING}

\subsection{COMPACT 6-4-2 VERSUS COMPACT 5-2-2}

Figure 1 shows the fractional release of key isotopes from AGR-2 UCO Compact 6-4-2 during safety testing at $1600^{\circ} \mathrm{C}$. This figure summarizes the overall estimated time-dependent fission product release from the safety test. The plotted data points represent the measured amount of each isotope collected on a deposition cup divided by the calculated amount of that isotope expected to be present as a result of the irradiation test [Sterbentz 2014] and adjusted for the deposition cup collection efficiency by dividing by the cumulative fraction of that isotope collected on the cups throughout the test (Table 2, Row 1). Cesium-137 is not reported because the released values were too low to accurately resolve from the contributions of hot cell contamination, which is high in the Irradiated Fuels Examination Laboratory (IFEL) hot cells due to six decades of release of this abundant and long-lived isotope. Results are presented below in the same manner for the other $1600^{\circ} \mathrm{C}$ safety tests. Note that deposition cup collection efficiencies were significantly higher for the more recent safety tests of Compacts 6-4-2 and 2-3-1. Collection efficiencies for the other two tests were abnormally low due to CCCTF operational problems during those runs, where the helium gas flow direction was inadvertently reversed.

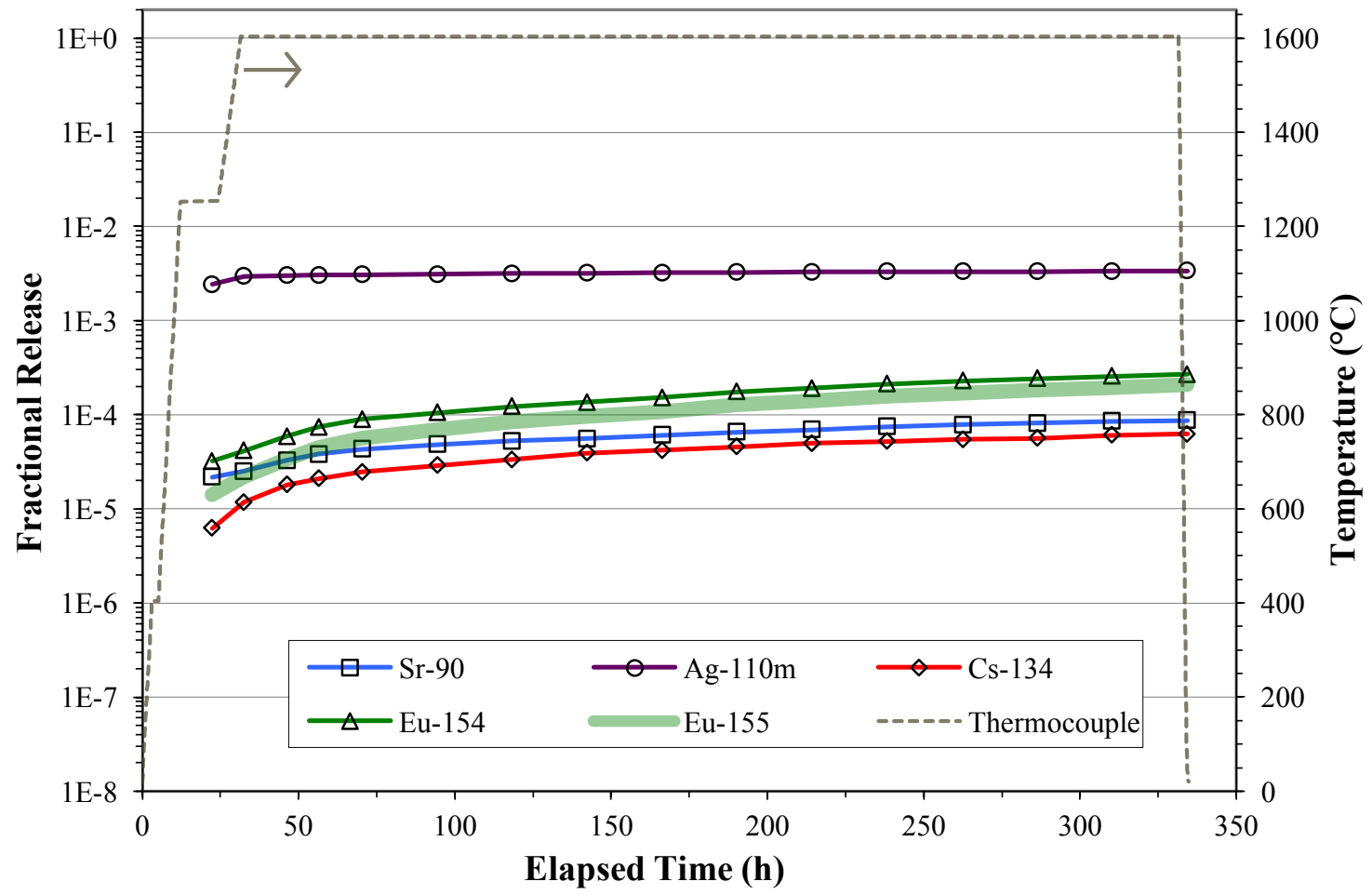

Figure 1. Release of fission products from Compact 6-4-2 during safety testing to $1600^{\circ} \mathrm{C}$.

Table 2. Radioactive isotope distribution on furnace internal components after the Compact 6-4-2 safety test

\begin{tabular}{lccccc}
\hline Component & ${ }^{90} \mathrm{Sr}$ & ${ }^{110 \mathrm{~m}} \mathrm{Ag}$ & ${ }^{134} \mathrm{Cs}$ & ${ }^{154} \mathrm{Eu}$ & ${ }^{155} \mathrm{Eu}$ \\
\hline Deposition cups & $94.5 \%$ & $100 \%$ & $62.5 \%$ & $59.5 \%$ & $46.2 \%$ \\
Tantalum parts & $1.9 \%$ & $\sim 0 \%$ & $18.1 \%$ & $\sim 0 \%$ & $\sim 0 \%$ \\
Graphite holder & $3.6 \%$ & $\sim 0 \%$ & $19.4 \%$ & $40.5 \%$ & $53.8 \%$ \\
\hline${ }^{137}$ Cs is not reported for Compact 6-4-2 because it was too low to measure above background contamination.
\end{tabular}


Figure 2 and Table 3 show the previously reported results for Compact 5-2-2 [Hunn et al. 2016a]. Both tests showed the same type of silver-release behavior; namely, the typical rapid release as compacts were brought to $1600^{\circ} \mathrm{C}$ of silver previously released through intact $\mathrm{SiC}$ during irradiation and held up in the graphite matrix and outer pyrocarbon (OPyC), and then relatively negligible additional release during the 300-h hold. Compact 6-4-2 released a smaller fraction of ${ }^{110 \mathrm{~m}} \mathrm{Ag}$, which is presumably due to the lower temperature irradiation resulting in less silver release through intact SiC. Lower silver release during irradiation is supported by compact gamma analysis with the INL Precision Gamma Scanner (PGS), which showed higher fractional release from Compact 5-2-2 (78.2\% versus 33.5\% of the calculated inventory [Harp et al. 2016]), and particle gamma scanning with the ORNL Irradiated Microsphere Gamma Analyzer (IMGA), which showed much higher fractional retention of ${ }^{110 \mathrm{~m}} \mathrm{Ag}$ in the particles from Compact 6-4-2 (Figure 3 and Figure 4).

Cesium release from Compact 6-4-2 was moderately elevated compared to Compact 5-2-2, whose ${ }^{134} \mathrm{Cs}$ release was less than $10^{-5}$. A ${ }^{134} \mathrm{Cs}$ release less than $10^{-5}$ was typical for compacts with no SiC failure during AGR-1 safety testing [Morris et al. 2014, figure 5]. However, the release from Compact 6-4-2 was lower than observed during $1600^{\circ} \mathrm{C}$ safety testing of AGR-1 compacts with $\mathrm{SiC}$ failure and only equivalent to about $20 \%$ of the average ${ }^{134} \mathrm{Cs}$ in a single particle, leaving it difficult to conclude from these results alone whether the ${ }^{134} \mathrm{Cs}$ release observed during the Compact 6-4-2 safety test was due to a particle with $\mathrm{SiC}$ failure or from contamination outside the $\mathrm{SiC}$.

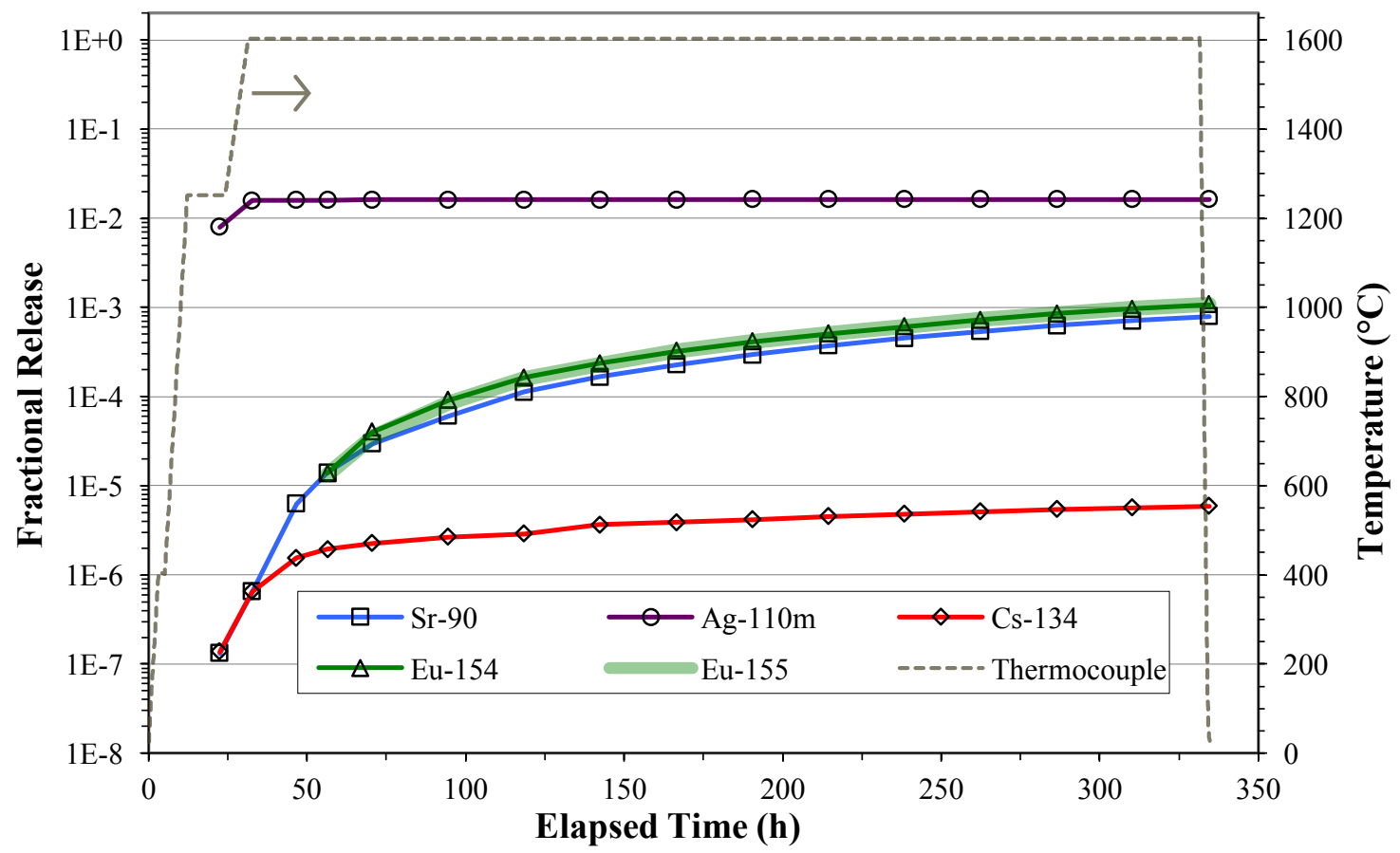

Figure 2. Release of fission products from Compact 5-2-2 during safety testing to $1600^{\circ} \mathrm{C}$.

Table 3. Radioactive isotope distribution on furnace internal components after the Compact 5-2-2 safety test

\begin{tabular}{lccccc}
\hline Component & ${ }^{90} \mathrm{Sr}$ & ${ }^{110 \mathrm{~m}} \mathrm{Ag}$ & ${ }^{134} \mathrm{Cs}$ & ${ }^{154} \mathrm{Eu}$ & ${ }^{155} \mathrm{Eu}$ \\
\hline Deposition cups & $4.8 \%$ & $32.9 \%$ & $18.6 \%$ & $2.1 \%$ & $1.9 \%$ \\
Tantalum parts & $22.3 \%$ & $67.1 \%$ & $81.4 \%$ & $9.6 \%$ & $9.1 \%$ \\
Graphite holder & $72.9 \%$ & $\sim 0 \%$ & $\sim 0 \%$ & $88.3 \%$ & $89.1 \%$ \\
\hline${ }^{137} \mathrm{Cs}$ is not reported for Compact 5-2-2 because it was too low to measure above background contamination.
\end{tabular}




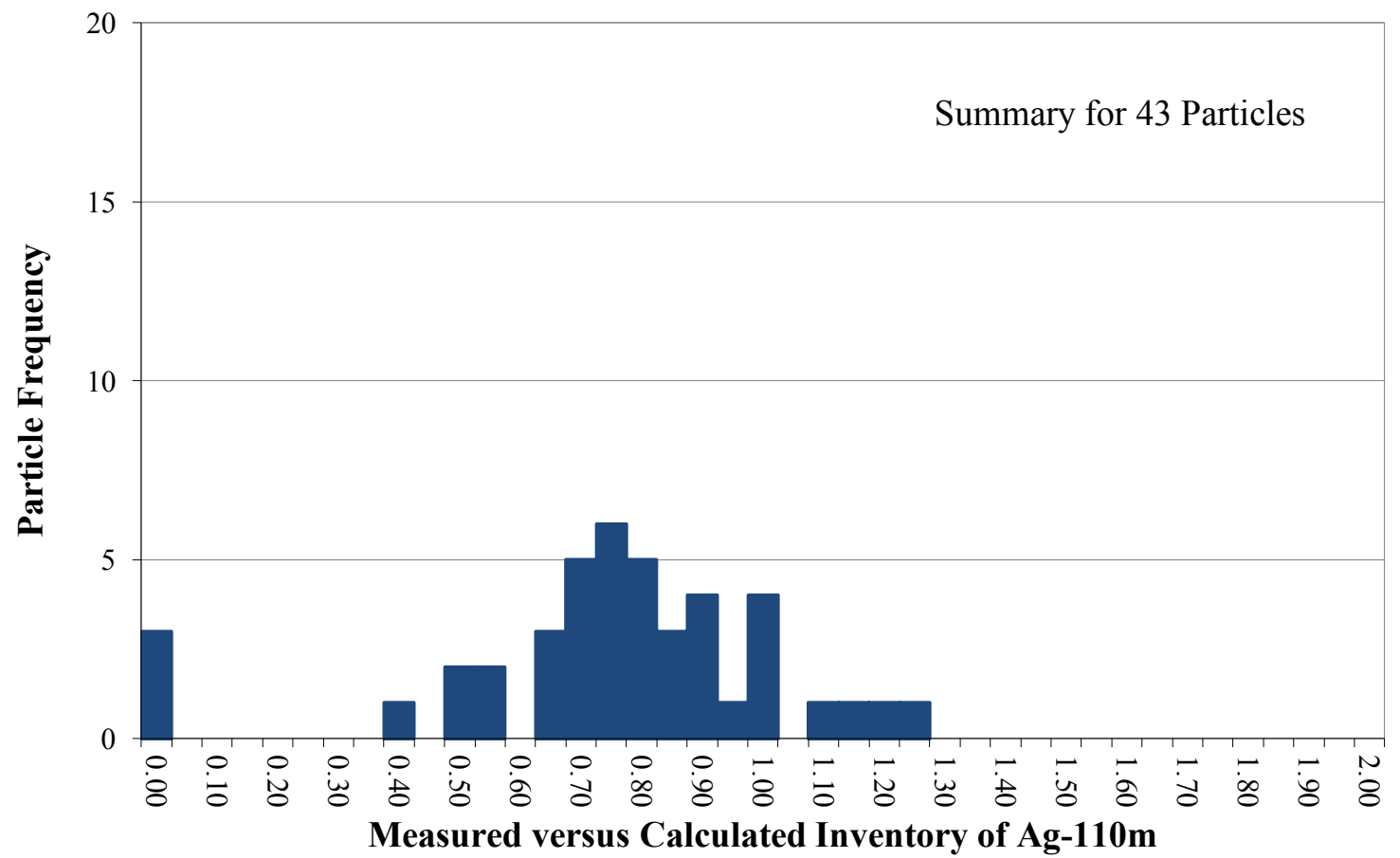

Figure 3. Ratio of ${ }^{110 \mathrm{~m}} \mathrm{Ag}$ retained in 43 Compact 6-4-2 particles after safety testing to $1600^{\circ} \mathrm{C}$ versus the calculated inventory, adjusted for variation in fissionable material and burnup with the measured ${ }^{137} \mathrm{Cs}$ activity. Particles plotted as "zero" had a measured to calculated ratio of $\mathrm{M} / \mathrm{C} \leqslant 33 \%$. The symmetric peak around $\mathrm{M} / \mathrm{C}$ of 0.75 indicates the ${ }^{110 \mathrm{~m}} \mathrm{Ag}$ inventory calculated value was probably higher than the true value.

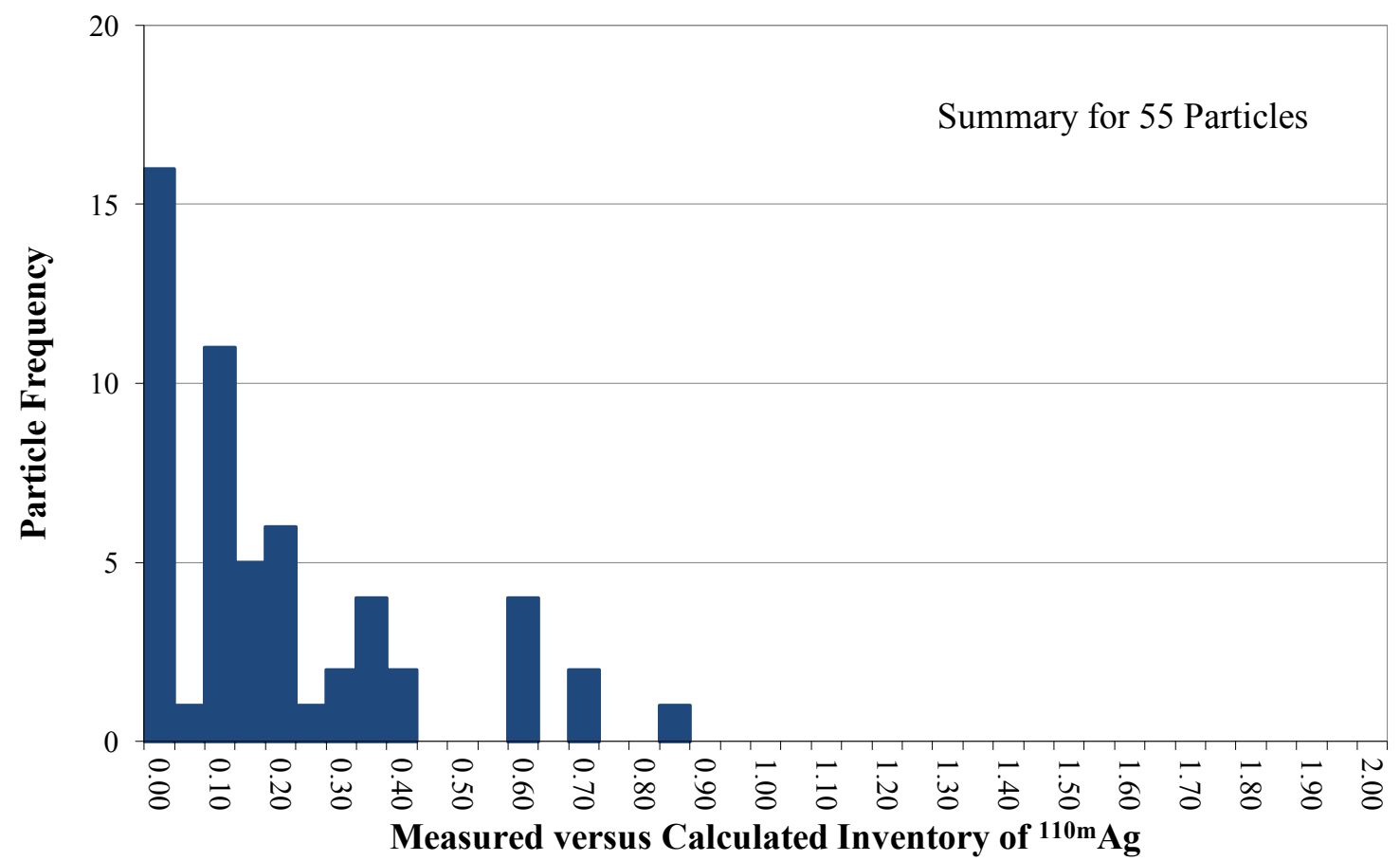

Figure 4. Ratio of ${ }^{110 \mathrm{~m}} \mathrm{Ag}$ retained in 55 Compact 5-2-2 particles after safety testing to $1600^{\circ} \mathrm{C}$ versus the calculated inventory, adjusted for variation in fissionable material and burnup with the measured ${ }^{137} \mathrm{Cs}$ activity. Particles plotted as "zero" had M/C $\$ 7.0 \%$. 
Figure 5 and Figure 6 show the same data for Compacts 6-4-2 and 5-2-2 as Figure 1 and Figure 2, respectively, with the data plotted in terms of average release rate to each deposition cup. These rate plots highlight the early silver release presumed to come from previous release under irradiation. Deposition cups taken at the end of the $1250^{\circ} \mathrm{C}, 12$-hour-hold and $1 \mathrm{~h}$ after the ramp to $1600^{\circ} \mathrm{C}$ had one to two orders of magnitude higher ${ }^{110 \mathrm{~m}} \mathrm{Ag}$ collection rates than later cups. Typically, a failed-SiC particle would similarly result in a clearly discernable peak in the ${ }^{134} \mathrm{Cs}$ release rate, but this was not evident in the Compact 6-4-2 data.

After safety testing, Compact 6-4-2 was subjected to deconsolidation leach-burn-leach (DLBL) analysis as described in Hunn et al. 2013. Only 5.8\% of one particle's inventory of ${ }^{238} \mathrm{U}$ was detected outside of intact $\mathrm{SiC}$ by this analysis. If a particle with failed $\mathrm{SiC}$ was present in this compact, there should have been close to a whole particle's inventory of ${ }^{238} \mathrm{U}$ detected in the post-burn leaches. This indicates that the observed cesium release during safety testing probably came from contamination outside the SiC, rather than a particle with failed $\mathrm{SiC}$.

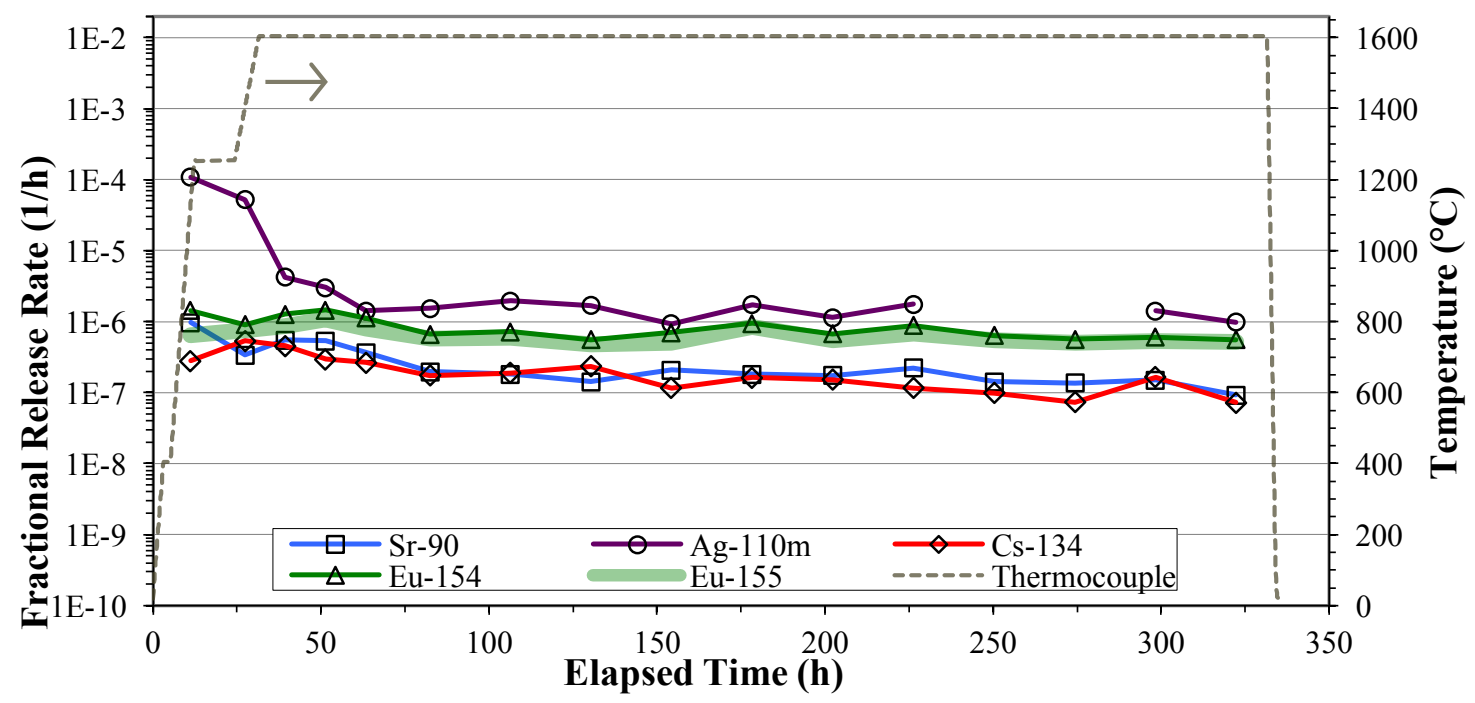

Figure 5. Rate of fission product release from Compact 6-4-2 during safety testing to $1600^{\circ} \mathrm{C}$.

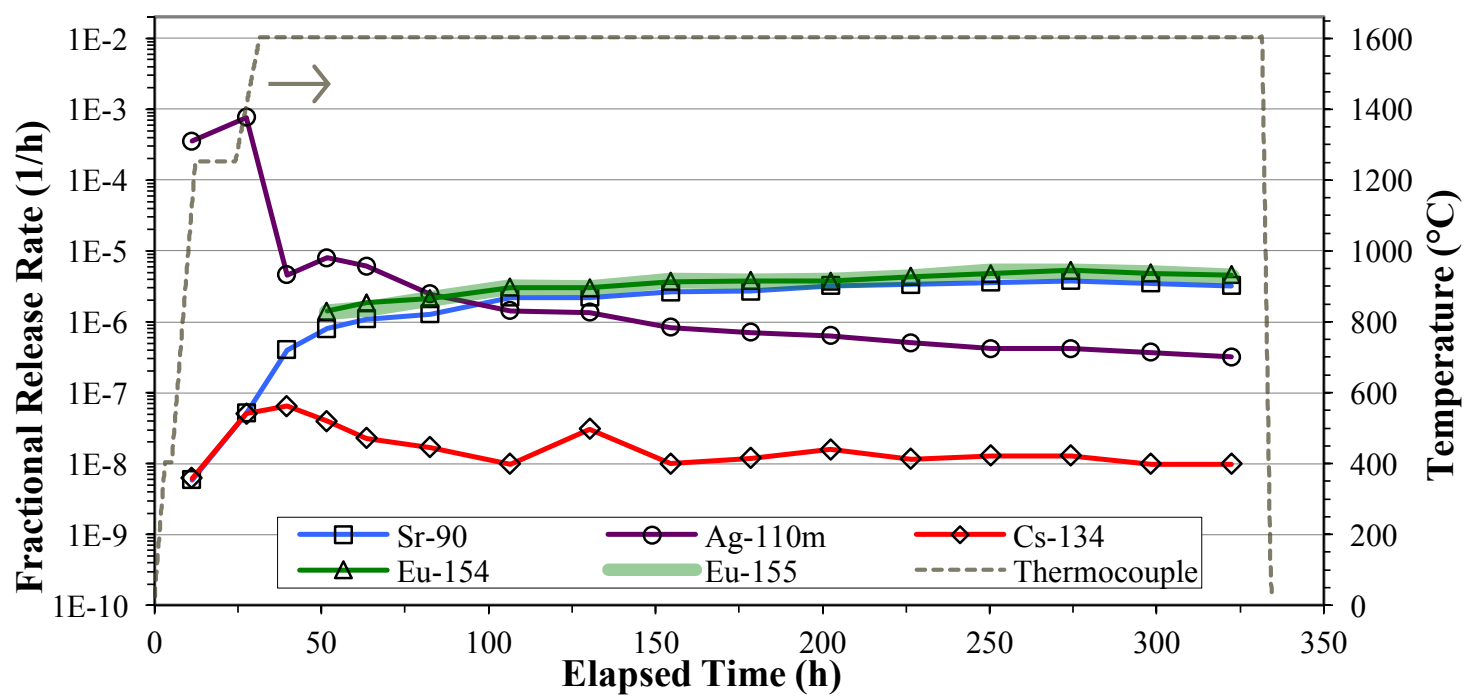

Figure 6. Rate of fission product release from Compact 5-2-2 during safety testing to $1600^{\circ} \mathrm{C}$. 


\subsection{COMPACT 2-3-1 VERSUS COMPACT 2-2-2}

Figure 7 shows the fractional release from $1600^{\circ} \mathrm{C}$ safety-tested Compact 2-3-1 and Figure 8 shows Compact 2-2-2 for comparison. Relative distribution of the isotopes to the furnace internals is provided in Table 4 and Table 5. Cesium release from these compacts was very low, indicating there were no particles with failed SiC. Release of silver during the ramp to $1600^{\circ} \mathrm{C}$ was followed by negligible additional release, while europium and strontium exhibited a roughly constant release rate after an initial period to reach equilibrium (Figure 9 and Figure 10). The primary explanation for differences in the magnitude of europium and strontium release during these two safety tests, compared to Compacts 6-4-2 and 5-2-2, is the higher irradiation temperature for the Capsule 2 compacts (Table 1), which resulted in greater quantities of europium and strontium being released during irradiation. Deconsolidation and LBL of asirradiated compacts [Hunn et al. 2016b] has shown there was a dramatically-higher inventory of europium and strontium outside of intact $\mathrm{SiC}$ in the Capsule 2 compacts at the end of irradiation, compared to compacts irradiated at lower temperature in other AGR-2 capsules or in AGR-1 [Demkowicz et al. 2015].

As discussed in a previous report [Hunn et al. 2017], in the absence of coating failure, the release behavior of silver, europium, and strontium during AGR-1 safety testing was attributed to release of fission products trapped in the compact matrix graphite and OPyC that had been previously released through intact $\mathrm{SiC}$ during the three-year irradiation [Morris et al. 2014]. This same mechanism is the most likely explanation for the observed release of these elements from AGR-2 compacts. The relatively rapid release of silver can be explained by its low-retention in the carbonaceous OPyC and matrix at elevated temperatures. The relatively slow release of europium and strontium, along with the initial delay in its collection on the deposition cups, can be explained by the fact that these elements diffuse through the $\mathrm{OPyC}$, matrix, and graphite holder at a much slower rate than silver or cesium. Table $2-$ Table 5 show that a large fraction of the europium and strontium released from the compacts was still in the graphite holder at the conclusion of the $1600^{\circ} \mathrm{C}$ safety tests.

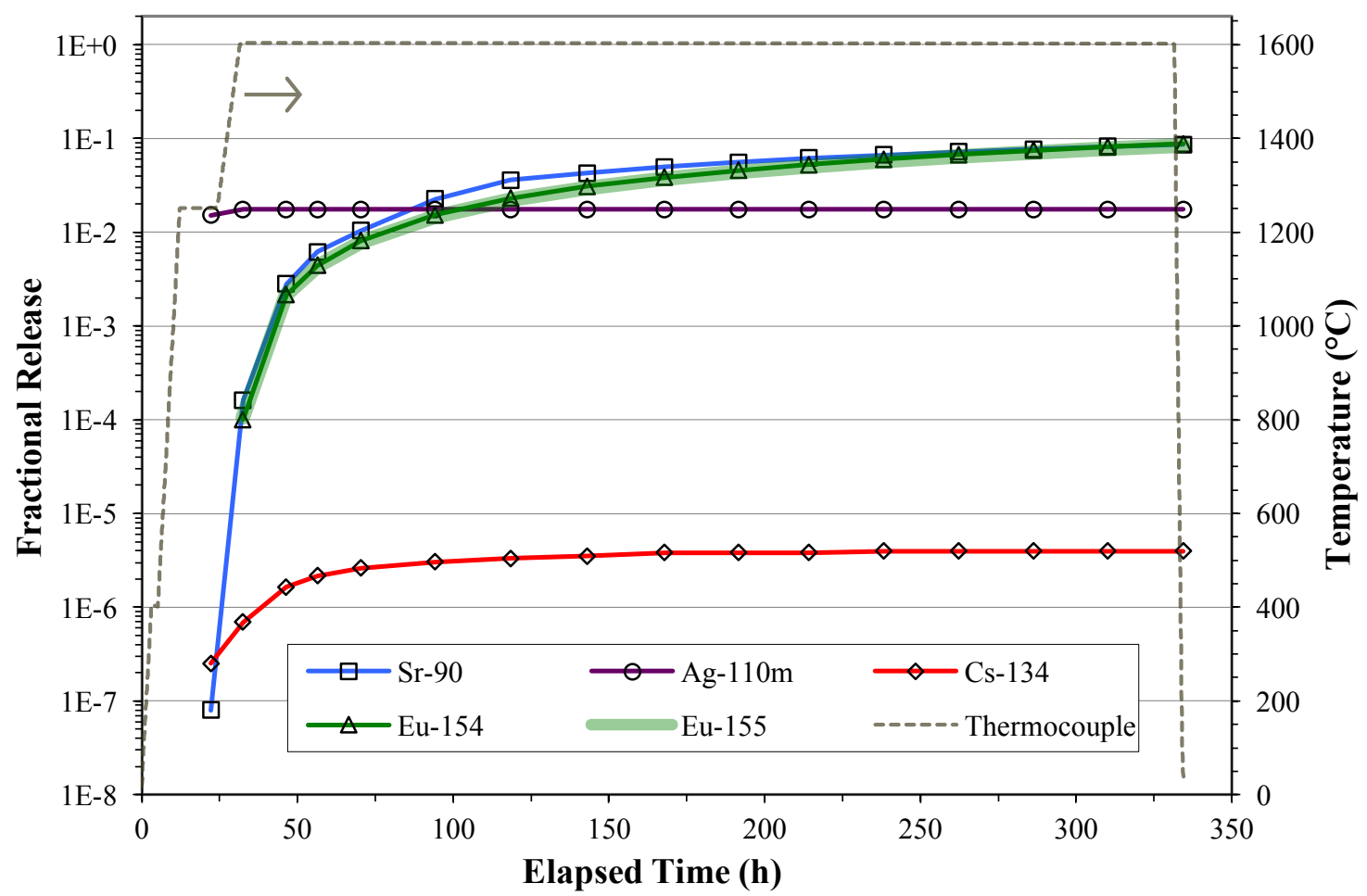

Figure 7. Release of fission products from Compact 2-3-1 during safety testing to $1600^{\circ} \mathrm{C}$. 
Table 4. Radioactive isotope distribution on furnace internal components after the Compact 2-3-1 safety test

\begin{tabular}{lccccc}
\hline Component & ${ }^{90} \mathrm{Sr}$ & ${ }^{110 \mathrm{~m}} \mathrm{Ag}$ & ${ }^{134} \mathrm{Cs}$ & ${ }^{154} \mathrm{Eu}$ & ${ }^{155} \mathrm{Eu}$ \\
\hline Deposition cups & $50.6 \%$ & $100 \%$ & $80.6 \%$ & $22.1 \%$ & $19.4 \%$ \\
Tantalum parts & $12.7 \%$ & $\sim 0 \%$ & $19.4 \%$ & $12.5 \%$ & $13.1 \%$ \\
Graphite holder & $36.7 \%$ & $\sim 0 \%$ & $\sim 0 \%$ & $65.5 \%$ & $67.6 \%$
\end{tabular}

${ }^{137} \mathrm{Cs}$ is not reported for Compact 2-3-1 because it was too low to measure above background contamination.

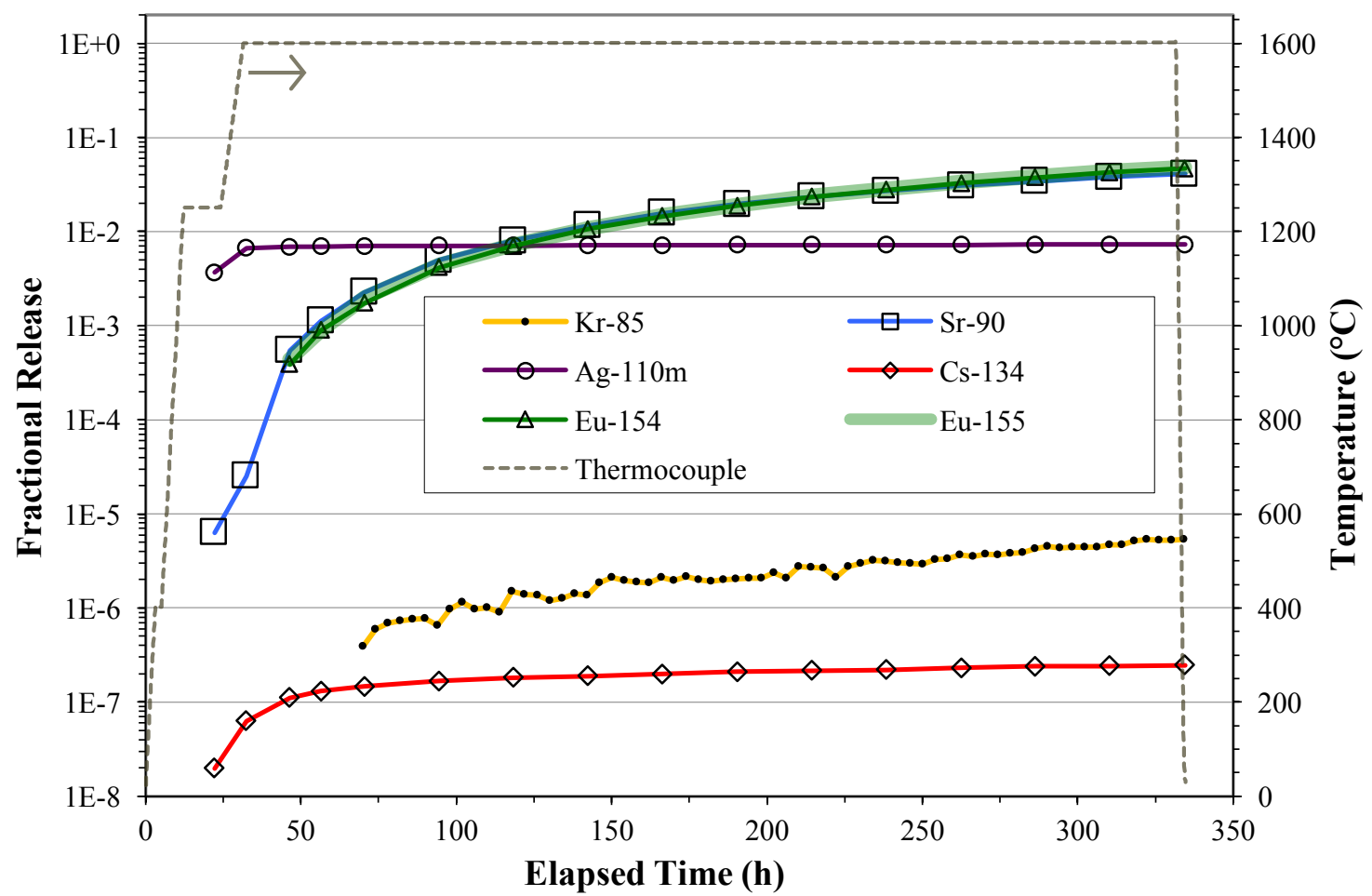

Figure 8. Release of fission products from Compact 2-2-2 during safety testing to $1600^{\circ} \mathrm{C}$. The ${ }^{85} \mathrm{Kr}$ release was too low to have come from a particle with failed TRISO and may have been from uranium in the matrix [Hunn et al. 2016a].

Table 5. Radioactive isotope distribution on furnace internal components after the Compact 2-2-2 safety test

\begin{tabular}{lccccc}
\hline Component & ${ }^{90} \mathrm{Sr}$ & ${ }^{110 \mathrm{~m}} \mathrm{Ag}$ & ${ }^{134} \mathrm{Cs}$ & ${ }^{154} \mathrm{Eu}$ & ${ }^{155} \mathrm{Eu}$ \\
\hline Deposition cups & $0.09 \%$ & $23.8 \%$ & $84.9 \%$ & $0.1 \%$ & $0.1 \%$ \\
Tantalum parts & $45.9 \%$ & $76.2 \%$ & $\sim 0 \%$ & $19.4 \%$ & $20.3 \%$ \\
Graphite holder & $54.0 \%$ & $\sim 0 \%$ & $15.1 \%$ & $80.5 \%$ & $79.6 \%$ \\
\hline
\end{tabular}




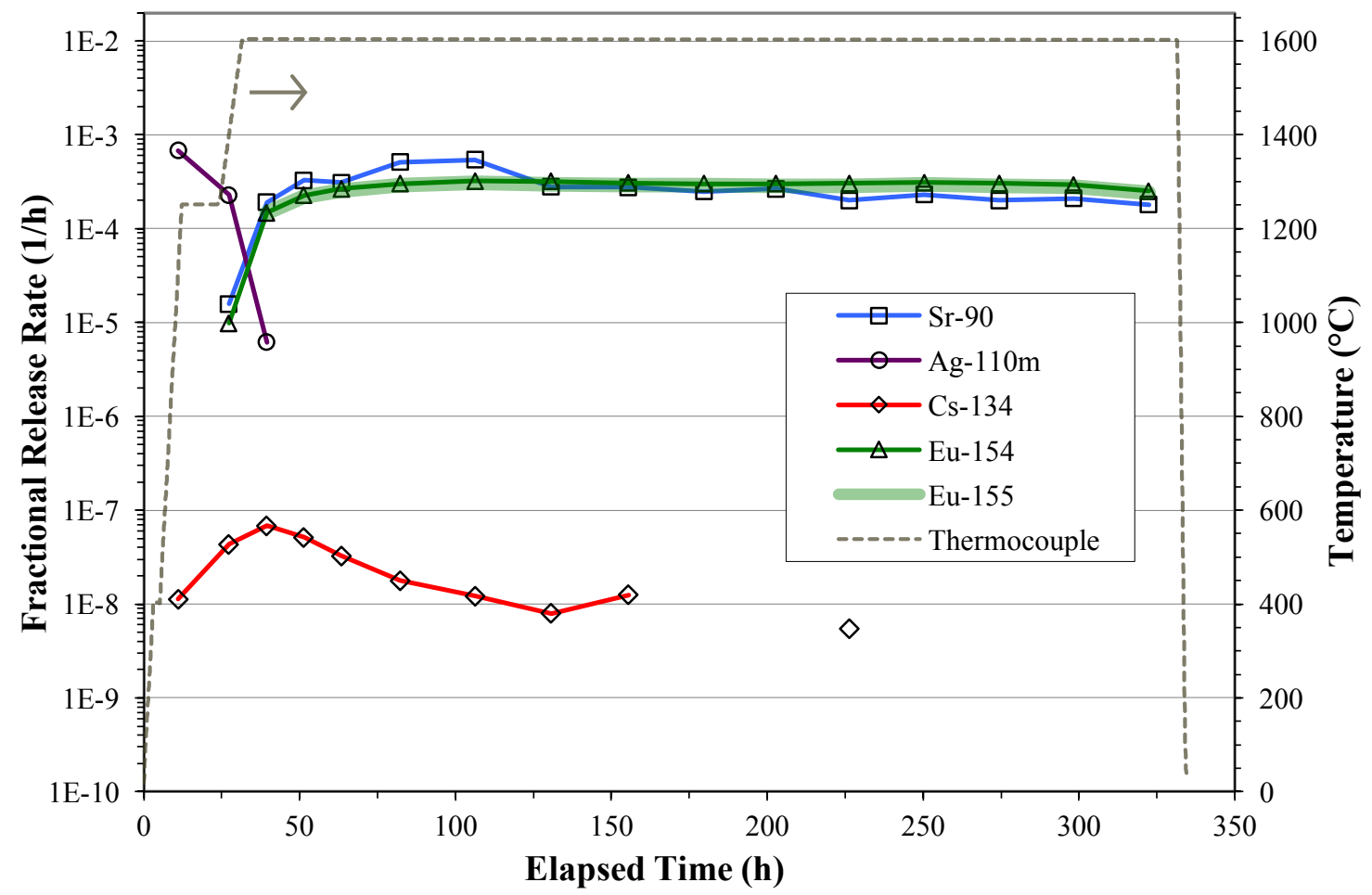

Figure 9. Rate of fission product release from Compact 2-3-1 during safety testing to $1600^{\circ} \mathrm{C}$ (data points with no measurable release rate are not plotted).

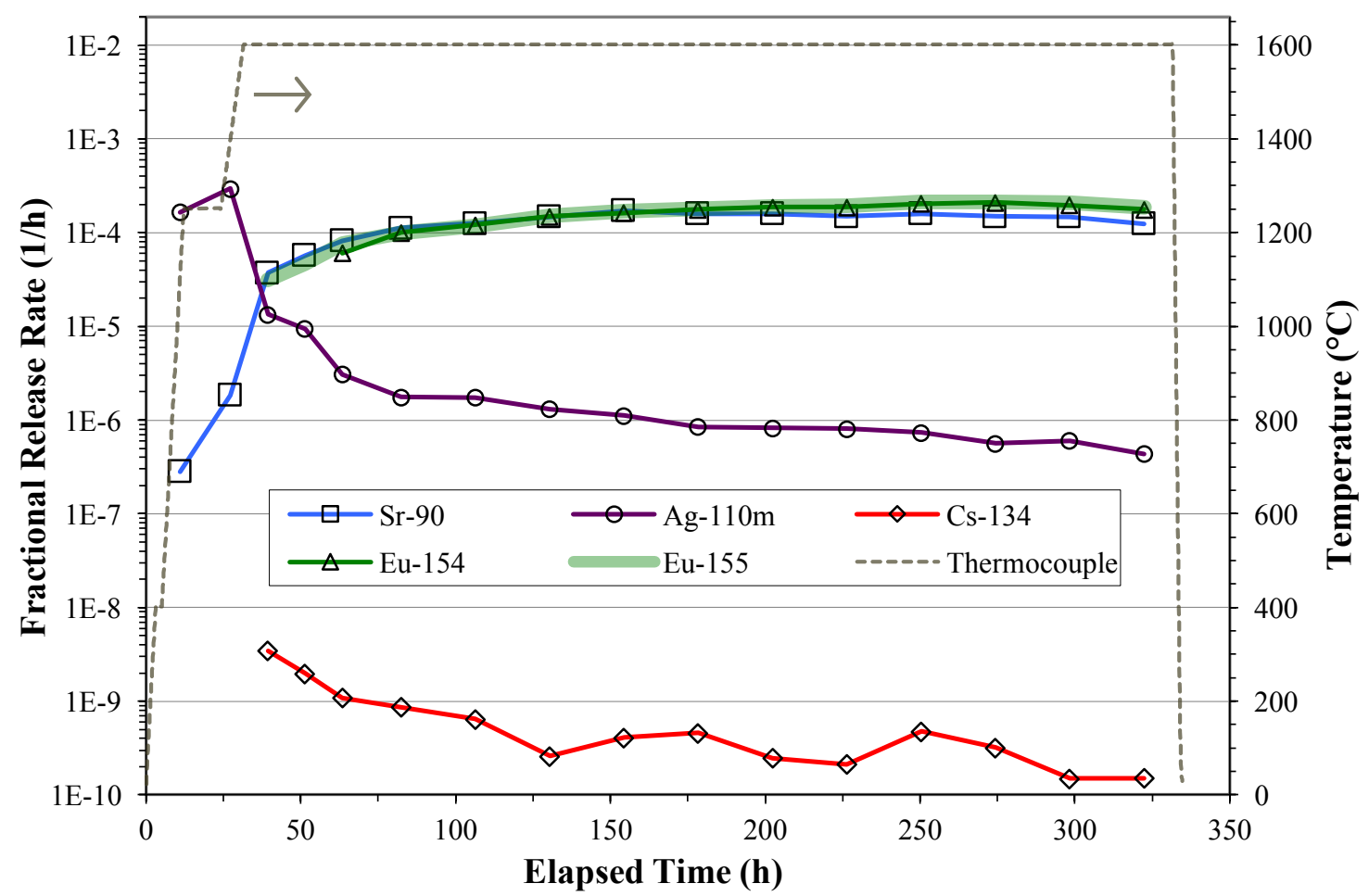

Figure 10. Rate of fission product release from Compact 2-2-2 during safety testing to $1600^{\circ} \mathrm{C}$. 


\section{CONCLUSION}

Safety testing at $1600^{\circ} \mathrm{C}$ was completed on AGR-2 UCO Compacts 6-4-2 and 2-3-1. Overall fission product release behavior was consistent with that observed for two previous AGR-2 UCO compact $1600^{\circ} \mathrm{C}$ safety tests [Hunn et al. 2016a] and safety tests on AGR-1 UCO compacts [Morris et al. 2014; Demkowicz et al. 2015]. Table 6 is a summary of the cumulative release from the four $1600^{\circ} \mathrm{C}$ safetytested AGR-2 UCO compacts. In general, there were no clear indicators for TRISO failure (sudden ${ }^{85} \mathrm{Kr}$ release or cumulative release comparable to a particle inventory) or failed $\mathrm{SiC}$ (sudden Cs release comparable to a few tenths or more of a particle inventory). A small amount of ${ }^{85} \mathrm{Kr}$ release during Compact 2-2-2 safety testing was too low to have come from a particle with failed TRISO and may have been from uranium in the matrix [Hunn et al. 2016a]. The cumulative ${ }^{134} \mathrm{Cs}$ release from Compact 6-4-2 reached $20 \%$ of one particle's inventory by the end of the safety test. This cesium release is a factor of 10 greater than expected from a compact with no $\mathrm{SiC}$ failure, but below what is typical for a compact with a failed-SiC particle. No exposed kernels were detected in Compact 6-4-2 during post-safety test DLBL and this led to the conclusion that the relatively-gradual release of cesium from Compact 6-4-2 was more likely related to uranium contamination in the matrix.

Table 6. Cumulative releases of radioactive isotopes from AGR-2 UCO TRISO $1600^{\circ} \mathrm{C}$ safety tests

\begin{tabular}{cccccccccc}
\hline \multirow{2}{*}{ Isotope } & \multicolumn{2}{c}{ Compact 6-4-2 } & \multicolumn{2}{c}{ Compact 5-2-2 } & \multicolumn{2}{c}{ Compact 2-3-1 } & \multicolumn{2}{c}{ Compact 2-2-2 } \\
\cline { 2 - 9 } & $\begin{array}{c}\text { Compact } \\
\text { fraction }\end{array}$ & $\begin{array}{c}\text { Particle } \\
\text { equivalent }\end{array}$ & $\begin{array}{c}\text { Compact } \\
\text { fraction }\end{array}$ & $\begin{array}{c}\text { Particle } \\
\text { equivalent }\end{array}$ & $\begin{array}{c}\text { Compact } \\
\text { fraction }\end{array}$ & $\begin{array}{c}\text { Particle } \\
\text { equivalent }\end{array}$ & $\begin{array}{c}\text { Compact } \\
\text { fraction }\end{array}$ & $\begin{array}{c}\text { Particle } \\
\text { equivalent }\end{array}$ \\
\hline${ }^{85} \mathrm{Kr}$ & $<9 \times 10^{-7}$ & $<0.002$ & $<7 \times 10^{-7}$ & $<0.002$ & $<7 \times 10^{-7}$ & $<0.002$ & $5.4 \times 10^{-6}$ & 0.017 \\
${ }^{90} \mathrm{Sr}$ & $8.7 \times 10^{-5}$ & 0.28 & $7.9 \times 10^{-4}$ & 2.5 & $8.6 \times 10^{-2}$ & 270 & $4.1 \times 10^{-2}$ & 130 \\
${ }^{110 \mathrm{~m}} \mathrm{Ag}$ & $3.4 \times 10^{-3}$ & 11 & $1.6 \times 10^{-2}$ & 52 & $1.8 \times 10^{-2}$ & 56 & $7.3 \times 10^{-3}$ & 23 \\
${ }^{134} \mathrm{Cs}$ & $6.2 \times 10^{-5}$ & 0.20 & $5.9 \times 10^{-6}$ & 0.019 & $4.0 \times 10^{-6}$ & 0.013 & $2.5 \times 10^{-7}$ & 0.00078 \\
${ }^{154} \mathrm{Eu}$ & $2.7 \times 10^{-4}$ & 0.85 & $1.1 \times 10^{-3}$ & 3.4 & $8.4 \times 10^{-2}$ & 280 & $4.7 \times 10^{-2}$ & 150 \\
${ }^{155} \mathrm{Eu}$ & $2.1 \times 10^{-4}$ & 0.66 & $1.1 \times 10^{-3}$ & 3.4 & $8.6 \times 10^{-2}$ & 270 & $4.8 \times 10^{-2}$ & 150 \\
\hline
\end{tabular}

Europium and strontium releases from Compact 6-4-2 were low enough that they may have also been impacted by this presumed uranium contamination. Overall, the measured fission product release at $1600^{\circ} \mathrm{C}$ appeared to be dominated by release of radioisotopes previously released under irradiation and subsequently retained in the carbonaceous matrix and OPyC until the compacts were heated above the irradiation temperature, as was observed for AGR-1 [Morris et al. 2014]. Release of europium and strontium from AGR-2 UCO Compacts 2-3-1 and 2-2-2 was very high but still consistent with release from the matrix and $\mathrm{OPyC}$, as the higher Capsule 2 irradiation temperatures resulted in significantlyhigher release of these isotopes [Hunn et al. 2016b]. Leach-burn-leach analysis is currently in progress on as-irradiated Compact 2-2-1, results from which a direct comparison can be made to the Compact 2-2-2 safety test releases, as these two compacts were irradiated to near-identical conditions. 


\section{REFERENCES}

Baldwin, C.A., J.D. Hunn, R.N. Morris, F.C. Montgomery, C.M. Silva, and P.A. Demkowicz. 2012. "First Elevated Temperature Performance Testing of Coated Particle Fuel Compacts from the AGR-1 Irradiation Experiment." Paper HTR2012-3-027 in Proceedings of the 6th International Topical Meeting on High Temperature Reactor Technology-HTR 2012, Tokyo, Japan, October 28November 1, 2012. Also published in Nucl. Eng. and Design 271: 131-141.

Barnes, C.M. and D.W. Marshall. 2009. FY 2009 Particle Fabrication and Coater Test Report. INL/EXT-09-16545, Revision 0. Idaho Falls, Idaho: Idaho National Laboratory.

Collin, B.P. 2014. AGR-2 Irradiation Test Final As-Run Report. INL/EXT-14-32277, Revision 2. Idaho Falls, Idaho: Idaho National Laboratory.

Demkowicz, P.A. 2013. AGR-2 Post Irradiation Examination Plan. PLN-4616, Revision 0. Idaho Falls, Idaho: Idaho National Laboratory.

Demkowicz, P.A., J.D. Hunn, R.N. Morris, I.J. van Rooyen, T.J. Gerczak, J.M. Harp, and S.A. Ploger. 2015. AGR-1 Post Irradiation Examination Final Report. INL/EXT-15-36407, Revision 0. Idaho Falls, Idaho: Idaho National Laboratory.

Gerczak, T.J., J.D. Hunn, R.A. Lowden, and T.R. Allen. 2016. "SiC Layer Microstructure in AGR-1 and AGR-2 TRISO Fuel Particles and the Influence of Its Variation on the Effective Diffusion of Key Fission Products." J. Nucl. Mater. 480: 1-14.

Harp, J.M., P.A. Demkowicz, and J.D. Stempien. 2016. "Fission Product Inventory and Burnup Evaluation of the AGR-2 Irradiation by Gamma Spectrometry", Paper HTR2016-18593. Proc. 8th International Topical Meeting on High Temperature Reactor Technology (HTR-2016), Las Vegas, Nevada, November 6-10, 2016.

Hawkes, G.L. 2014. AGR-2 Daily As-Run Thermal Analyses. INL/ECAR-2476, Revision 1. Idaho Falls, Idaho: Idaho National Laboratory.

Hunn, J.D. and R.A. Lowden. 2006. Data Compilation for AGR-1 Variant 3 Coated Particle Composite LEU01-49T. ORNL/TM-2006/022, Revision 0. Oak Ridge, Tennessee: Oak Ridge National Laboratory.

Hunn, J.D. 2010. AGR-2 Fuel Compacts Information Summary: Prepared for the NRC MELCOR Project. ORNL/TM-2010/296, Revision 1. Oak Ridge, Tennessee: Oak Ridge National Laboratory.

Hunn, J.D., F.C. Montgomery, and P.J. Pappano. 2010a. Data Compilation for AGR-2 UCO Variant Compact Lot LEU09-OP2-Z. ORNL/TM-2010/017, Revision 1. Oak Ridge, Tennessee: Oak Ridge National Laboratory.

Hunn, J.D., F.C. Montgomery, and P.J. Pappano. 2010b. Data Compilation for AGR-2 UO ${ }_{2}$ Compact Lot LEU11-OP2-Z. ORNL/TM-2010/055, Revision 1. Oak Ridge, Tennessee: Oak Ridge National Laboratory.

Hunn, J.D., T.W. Savage, and C.M. Silva. 2010. AGR-2 Fuel Compact Pre-Irradiation Characterization Summary Report. ORNL/TM-2010/226, Revision 0. Oak Ridge, Tennessee: Oak Ridge National Laboratory.

Hunn, J.D., T.W. Savage, and C.M. Silva. 2012. AGR-1 Fuel Compact Pre-Irradiation Characterization Summary Report. ORNL/TM-2012/295, Revision 0. Oak Ridge, Tennessee: Oak Ridge National Laboratory. 
Hunn, J.D., R.N. Morris, C.A. Baldwin, F.C. Montgomery, C.M. Silva, and T.J. Gerczak. 2013, AGR-1 Irradiated Compact 4-4-2 PIE Report: Evaluation of As-Irradiated Fuel Performance with Leach Burn Leach, IMGA, Materialography, and X-ray Tomography. ORNL/TM-2013/236, Revision 0. Oak Ridge, Tennessee: Oak Ridge National Laboratory.

Hunn, J.D., C.A. Baldwin, T J. Gerczak, F.C. Montgomery, R.N. Morris, C.M. Silva, P.A. Demkowicz, J.M. Harp, S.A. Ploger, I.J. van Rooyen, and K.E. Wright. 2014a. "Detection and Analysis of Particles with Failed SiC in AGR-1 Fuel Compacts." Paper HTR2014-31254 in Proceedings of the HTR 2014, Weihai, China, October 27-31, 2014. Also published in Nucl. Eng. Design 360: 36-46.

Hunn, J.D., R.N. Morris, C.A. Baldwin, and F.C. Montgomery. 2015a, Safety-Testing of AGR-2 UO, Compacts 3-3-2 and 3-4-2. ORNL/TM-2015/388, Revision 0. Oak Ridge, Tennessee: Oak Ridge National Laboratory.

Hunn, J.D., R.N. Morris, C.A. Baldwin, and F.C. Montgomery. 2016a, Safety-Testing of AGR-2 UCO Compacts 5-2-2, 2-2-2, and 5-4-1. ORNL/TM-2016/423, Revision 1. Oak Ridge, Tennessee: Oak Ridge National Laboratory.

Hunn, J.D., C.A. Baldwin, F.C. Montgomery, T.J. Gerczak, R.N. Morris, G.W. Helmreich, P.A. Demkowicz, J.M. Harp, and J.D. Stempien. 2016b. "Initial Examination of Fuel Compacts and TRISO Particles from the US AGR-2 Irradiation Test." Paper HTR2016-18443. Proc. 8th International Topical Meeting on High Temperature Reactor Technology (HTR-2016), Las Vegas, Nevada, November 6-10, 2016.

Lowden, R.A. 2006. Fabrication of Baseline and Variant Particle Fuel for AGR-1. ORNL/CF-2006/02, Revision 0. Oak Ridge, Tennessee: Oak Ridge National Laboratory.

Morris, R.N., P.A. Demkowicz, J.D. Hunn, C.A. Baldwin, and E.L. Reber. 2014. "Performance of AGR-1 High Temperature Reactor Fuel During Post-Irradiation Heating Tests." Paper HTR2014-31135 in Proceedings of the HTR 2014, Weihai, China, October 27-31, 2014. Also published in Nucl. Eng. Design 360: 24-35.

Morris, R.N., J.D. Hunn, C.A. Baldwin, F.C. Montgomery, T.J. Gerczak, and P.A. Demkowicz. 2016. "Initial Results from Safety Testing of US AGR-2 Irradiation Test Fuel." Paper HTR2016-18574. Proc. 8th International Topical Meeting on High Temperature Reactor Technology (HTR-2016), Las Vegas, Nevada, November 6-10, 2016. Also to appear in Nucl. Eng. Design, https://doi.org/10.1016/ j.nucengdes.2017.08.006.

Phillips, J.A., C.M. Barnes, and J.D. Hunn. 2010. "Fabrication and Comparison of Fuels for Advanced Gas Reactor Irradiation Tests." Paper HTR2010-236 in Proceedings of the 5th International Topical Meeting on High Temperature Reactor Technology, HTR 2010, Prague, Czech Republic, October 18 20, 2010.

Sterbentz, J.W. 2014. JMOCUP As-Run Daily Depletion Calculation for the AGR-2 Experiment in the ATR B-12 Position. ECAR-2066, Revision 2. Idaho Falls, Idaho: Idaho National Laboratory. 